ALEKSIEJ MILLER

Central European University, Budapest

\title{
KONCEPCJE REGIONALNEGO PODZIAEU EUROPY TO PRZEDMIOT BADAŃ GEOGRAFII MENTALNEJ. I TYLE
}

1. Czy regionalny podział (Europy? świata?) ma w ogóle sens jako schemat konceptualny dla historyka? Jeśli tak, to czy podział ten ma się opierać na kryterium samoświadomości mieszkańców danego regionu w danej epoce, czy też może być wniesiony z zewnątrz przez mieszkańców innych regionów (w naszym wypadku przez Zachód Europy) bądź też przez późniejszych historyków? Jeśli nie, to jakie inne ogólne schematy konceptualne rozumienia dziejów (problemowy? chronologiczny? badanie powiązań w ramach tzw. entangled history?) są bardziej obiecujące?

Jeżeli badamy świadomość mieszkańców regionu - to chodzi o „identity". Jeżeli badamy koncepcje geografii mentalnej, miedzy innymi wyobrażenie Zachodu Europy o innych terenach i ich mieszkańcach - to chodzi o „mental mapping”, koncepcje „Innego” itd. To wszystko ma sens, i historycy tym się zajmują od kilkudziesięciu lat. Historyk, który chce wykorzystać ten czy inny schemat regionalnego podziału Europy czy świata, powinien przede wszystkim się zastanowić, w jakim zakresie ten schemat może być właśnie przedmiotem badań nad mentalnymi mapami - to znaczy,jakie ma polityczne implikacje, jakie polityczne interesy odzwierciedla. Bez takiej wstępnej analizy badacz jest skazany na rolę ofiary ideologicznych schematów. Powinien także unikać esencjalizacji tych pojęć regionów, którymi się posługuje - to znaczy pamiętać, że jest to tylko instrument poznawczy. Kiedy próbuje udowodnić, iż ten czy ów region istnieje czy istniał naprawdę - już jest blisko niebezpieczeństwa zamiany instrumentu poznawczego w instrument ideologiczny. Poza tym powinien mieć na uwadze, że geografia regionów może drastycznie się zmieniać nie tylko w zależności od epoki, ale również w zależności od tematu. Zawsze punktem 
wyjścia ma być nie koncept regionu, lecz pytanie, jaki proces, jaką interakcję badamy, kto w tym uczestniczy, i dopiero potem wypada określić, jaki geograficzny zakres ma mieć nasz program badawczy.

W praktyce częściej wykorzystanie konceptów regionalnego podziału Europy przez historyków stwarza więcej problemów niż możliwości, gdyż rzadko kiedy historycy potrafią być wystarczająco krytyczni wobec tych map mentalnych.

2. Czy interesujący nas region zawsze był peryferią, czy może należał w niektórych epokach, pod niektórymi względami do zachodnioeuropejskiego centrum, a może tworzył centrum alternatywne i miał szanse na wytworzenie w pewnych epokach (jakich?) odrębnego niż zachodni modelu rozwojowego? Czy podział centrum/peryferie jest częściej „kompleksowy”, czy „wyspowy”, tzn. czy peryferyjny status dotyczy zwykle większości dziedzin życia społecznego, czy tylko niektórych? Czy podział ten jest ostry, czy też niezbędne jest wprowadzanie kategorii pośrednich, takich jak semiperyferie?

Tak więc jaki to region nas interesuje? Europa Wschodnia, Środkowa czy Środkowo-Wschodnia? I jeżeli bierzemy te koncepty zbyt serio, to już stoimy przed kolejną rundą już dosyć nudnej dyskusji na ten temat. Cała ta przestrzeń była, moim zdaniem, przez cały okres, na którym trochę się znam, to znaczy XVIII-XX w., peryferią w stosunku do tego, co nazywamy od XVII-XVIII w. Zachodem Europy, czyli klasteru urbanistycznego rozwoju, który został opisany przez S. Rokkana ${ }^{1}$. Inna sprawa, że na tej przestrzeni były centra i peryferie, które się zmieniały. Próba opisu tych zmian przez pojęcia Europy Wschodniej, Środkowej czy Europy Środkowo-Wschodniej tylko utrudnia nam zadanie - bo zmiany polityczne, ekonomiczne, cywilizacyjne były tu dramatyczne, a my będziemy szukali przeważnie ciągłości, próbując udowodnić istnienie przez cały okres tego naszego „ulubionego" regionu - na przykład Europy Środkowo-Wschodniej.

3. Czy ewentualne podobieństwa między różnymi krajami naszego regionu wynikają z wzajemnej bliskości geograficznej, czy może z położenia peryferyjnego względem centrum? A jeżeli to drugie, to może należałoby pisać historię europejskiej peryferii, która obejmowałaby także Irlandię, Szkocję, Portugalię itp., a nie historię Europy Środkowej (Wschodniej, itp.)?

Widzę w tym pytaniu kilka pomieszanych problemów. Otóż kraje naszego regionu są tworem XX w., a do tego czasu były to prowincje różnych imperiów, które miały różne stosunki z różnymi centrami tych im-

${ }^{1}$ S. Rokkan, Nation-Building. A Review of Models and Approaches, w: Nation-Building, red. S. Rokkan, K. Saelen, J. Warmbrunn, The Hague-Paris 1971, s. 7-38. 
periów albo same pełniły role takich centrów. I drugi problem, że owe imperia istotnie były peryferyjne w Europie, chociaż każde $\mathrm{z}$ tych imperiów w sposób mniej lub bardziej udany próbowało dostosować się do nowych czasów. Projekty ujmujące historie Imperium Rosyjskiego, Osmańskiego, Habsburskiego, Hiszpańskiego jako europejskiej peryferii już istnieją, i to jest krok we właściwym kierunku.

4. Czy określenia „Europa Środkowa” bądź „Środkowo-Wschodnia” są jedynie konwencjonalne, czy niosą ze sobą jakąś istotną treść; jeśli tak, to jak peryferia może być zarazem „środkiem”? Między czym a czym? Co byłoby wyznacznikiem owej „środkowości”, bycia „pomiędzy”?

To są koncepty ideologiczne i dobrze wiemy, kiedy były stworzone, miedzy innymi przez Oskara Haleckiego. ,Środek” tu pełni funkcję przede wszystkim odgraniczającą od Rosji i od konceptu Europy Wschodniej, do której Polskę zaliczano razem z Rosją. Środkowo-Wschodnia Europa była potrzebna przede wszystkim polskim ideologom, bo miała objąć , Jagiellońską" Polskę, razem z kresami wschodnimi. Koncept Europy Środkowej przeżył szczyt swojej kariery w latach 1970-1990, kiedy odegrał istotną rolę w zmianie dyskursu zachodniego o krajach Układu Warszawskiego, a potem w szybkim wejściu czwórki wyszehradzkiej do Unii Europejskiej. W XIX w., nie używając konceptu Środkowej Europy, wielu myślicieli omawiało problemy „małych” narodów znajdujących się między Niemcami a Rosją. Ale Niemcy używali pojęcia Mitteleuropa (Friedrich Naumann) na początku XX w. w zupełnie innym sensie - jako określenia przestrzeni przyszłej dominacji niemieckiej.

Jeżeli patrzymy na historię tej przestrzeni bardziej przez prymat historii imperiów, a nie historii narodowej, to znaczenie tych określeń regionalnych maleje albo nabiera innego sensu.

5. W jakich zjawiskach historycznych widziałby Pan Profesor specyfikę interesującego nas regionu; przy badaniu jakich zjawisk podejście regionalne może być badawczą korzyścią? Przychodzą do głowy kwestie takie, jak kwestia tworzenia się państw we wczesnym średniowieczu, problem dualizmu gospodarczego Europy, wczesnonowożytne podziały religijne (problem tolerancji; unie kościelne; kontrreformacyjna religijność w Rzeczypospolitej i krajach habsburskich), specyfika procesów narodotwórczych w XIX i XX w. (czy rozróżnienia typu „naród kulturowy/polityczny”, „naród historyczny/niehistoryczny” mają sens?), rytm powtarzających się prób modernizacyjnych od oświecenia po nasze czasy, doświadczenie komunizmu... Zapewne wiele ważnych problemów zostało tu pominiętych, bylibyśmy wdzięczni za ich wskazanie. 
Mogę mówić tylko w zakresie swojej kompetencji, czyli o XIX i XX w. Łatwiej mi będzie opisać różnice między modelami tworzenia narodów w imperium Habsburgów, Hohenzollernów, Osmanów i Romanowów niż w Europie Wschodniej, Środkowej czy Południowo-Wschodniej. Rozróżnienia typu „naród kulturowy/polityczny”, „naród historyczny/niehistoryczny" mają sens, tylko nie wyczerpują różnic, o których historycy mówią za pomocą tych konceptów. Czasami używanie tych dychotomii więcej stwarza problemów, niż ich rozwiązuje. Na przykład, w tych kategoriach nie da się opisać, jaką rolę odgrywały w tworzeniu narodów podporząadkowanych projekty budowania narodów imperialnych. Są to bowiem różne historie, w zależności od tego, czy pewna grupa jest przez projekt imperialny włączana do narodu imperialnego, jak Białorusini do „trzech części narodu rosyjskiego", razem z wielkorusami i małorusami, czy nie jest włączana, jak Litwini czy Estończycy. Wiele zależy też od tego, kiedy ten projekt narodu imperialnego jest forsowany - wcześniej, jak w II Rzeszy niemieckiej, czy później, jak w Porcie Ottomańskiej.

Doświadczenie komunizmu również można i warto opisać bez koncentracji na pojęciu Środkowa czy Wschodnia Europa - ponieważ obejmuje ono także Bułgarię, Rumunię, Jugosławię, NRD, które nie należą do tych regionów, jeżeli już chcemy koniecznie tymi pojęciami się posługiwać.

Co do cyklów modernizacyjnych, to na pewno muszą być badane z perspektywy peryferii ogólnoeuropejskiej.

Podsumowując - w mojej pracy pojęć Wschodnia, Środkowa czy Środkowo-Wschodnia Europa na serio nie używam, bo moim zdaniem to stwarza więcej problemów, niż daje korzyści, po pierwsze z powodu wieloletniej tradycji ideologicznego wykorzystywania tych pojęć, po drugie dlatego, że wydaje mi się, iż to, co historycy mogli osiągnąć, wykorzystując te pojęcia jako rodzaj instrumentu analitycznego, już zdobyli i warto wykorzystać potencjał innych podejść, a mianowicie perspektywę imperiologii i perspektywę „,wallersteinowską", czyli ogólnoeuropejskiej peryferii. 